DOI 10.31558/2519-2949.2021.4.10

УДК 321.32:159.9

ORCID ID: https://orcid.org/0000-0003-3281-6138

Шайгородський Ю. Ж., Інститут політичних і етнонаціональних досліджень ім. І. Ф. Кураса НАН Украӥни

\title{
ДОВІРА ЯК ПОЛІТИКО-ПСИХОЛОГІЧНИЙ ФЕНОМЕН
}

Статтю присвячено аналізові довіри як політико-психологічного феномену. Зосереджено увагу на тому, що довіра є иіннісною основою соиіальної взаємодії, наголошено, що ефективність иієї взаємодії базується на збігові цінностей, чим, значною мірою, забезпечується иіннісноорієнтаційна єдність. Підкреслено, що унікальність явища довіри полягає у своєрідному поєднанні рачіональних та позараціональних підстав оцінок і суджень. Доведено, щяо довіра, з одного боку, $\epsilon$ результатом апостеріорного пізнання й випливає з досвіду, трунтується на аналізі й синтезі подій, явищ, процесів, оцінки поведінки тощо, з другого - базується на ірращіональних мотивах з покладанням на інтуїиію, власні або ж стереотипні уявлення про належне, бажане, вірогідне через переважно емоційне його сприйняття. Обтрунтовано роль довіри як важливого чинника державотворчих прочесів в умовах начіонального, державного самовизначення та подолання суспільно-політичних криз. Особливу увагу приділено ролі довіри в процесі легітимаиї̈ влади, актуалізовано проблему довіри в контексті взаємодії гілок влади, політичних та державних інститутів. Доведено, щьо довіра як політико-психологічне явище є потужним чинником $i$ регулятором суспільно-політичних процесів, елементом архітектури системи соціальної та інституиійної взаємодії та своєрідною формою ї̈ забезпечення. В контексті суспільно-політичної взаємодї̈ розкрито сочіально-психологічну основу розрізнення понять «довіра» $i$ «віра», «довіра» $i$ «недовіра». Окреслено характерні риси й визначено окремі функиї̈ довіри як соиіокультурного $і$ політико-психологічного феномену. Наголомено на когнітивній функиії довіри, зокрема, на необхідності розвитку політичного мислення як аналітичної передумови довіри та необхідної складової політичної культури.

Ключові слова: довіра, цінності, сочіальна взаємодія, політичне мислення, раціональне та ірраціональне в політиці, політична культура.

Постановка проблеми. Характерною ознакою сучасного етапу суспільного поступу $є$ високий рівень його динамічності й мінливості під впливом зовнішньо- і внутрішньополітичних чинників. В умовах зміни ціннісних парадигм на тлі переосмислення суспільно-політичних процесів і явищ особливої ваги набувають феномени, які забезпечують єдність і стабільність соціуму, прогнозованість його розвитку. Одним з таких феноменів є довіра як складова почасти суперечливої, але цілісної системи взаємопов'язаних, взаємозалежних і взаємозумовлених елементів суспільної взаємодії. В цьому сенсі довіра $є$ своєрідним індикатором і водночас- необхідною умовою соціальної впорядкованості й ефективності спільнодії.

Поняття довіри як явища моральної свідомості, сукупності певних чеснот, як показник авторитету та рівня відповідальності, як необхідного, базового елементу демократії, зрештою - як соціального інституту, постійно присутнє у комунікаційній і предметній взаємодії, у публічних виступах, риториці політиків, журналістів, експертів. Довіра та апеляція до неї є неодмінним атрибутом оцінки суспільних процесів і явищ, підставою прийняття й реалізації політичних й управлінських рішень, передбачення соціально-політичної поведінки, електорального вибору, мобілізації мас тощо. Водночас сутність цього феномену, його витоки та роль у суспільно-політичних процесах, попри чималу дослідницьку увагу до філософських, соціологічних, психологічних та окремих політологічних аспектів довіри як соціального явища, залишаються малодослідженими.

Метою та завданнями статті $є$ аналіз довіри як політико-психологічного феномену, його дослідження як аксіологічного явища, складової процесу становлення ідентичності, а такожобгрунтування необхідності урахування фактору довіри як чинника державотворчих процесів, базового елементу демократичного розвитку. 
Дослідження виконано з опертям на методи загальнонаукового, філософського, системного, логічного, структурно-функціонального, соціально- та політико-психологічного аналізу. Використання цих методів уможливило, з одного боку, цілісне сприйняття об'єкта дослідження в поєднанні його зв'язків і взаємозалежностей, з другого - виокремлення функцій, визначення спрямованості та можливих напрямів підвищення рівня суспільної довіри як складової процесу державотворення.

Системний аналіз наукових публікацій з проблем довіри як соціального явища засвідчив наявність різних підходів до трактування й визначення поняття, а також - багатоаспектність проявів. У наукових публікаціях довіра постає важливою передумовою, необхідною складовою та водночас результатом суспільного розвитку. Проблемі довіри, як важливої характеристики розвиненості соціальних та політичних відносин, присвячено праці авторитетних науковців. Серед дослідників явища довіри в цьому контексті У. Бек [1], П. Бурдьє [2; 3], Е. Гідденс [4], М. Ліпсет [5], Н. Луман [6], А. Маслоу [7], Т. Парсонс [8], А. Селігмен [9], Ф. Фукуяма [10], П. Штомпка [11; 12] та ін. До проблеми довіри звертаються у своїх наукових розвідках і вітчизняні вчені А. Бова [13], О. Вишняк, С. Головаха [14], С. Денисюк [15], А. Ручка [16], Г. Щедрова [17], інші науковці.

Значущість регуляторної функції довіри у суспільному розвитку та роль соціальної взаємодії в ефективності цього процесу переконливо доводить Ф. Фукуяма, визначаючи довіру своєрідним продуктом соціального капіталу; для П. Бурдьє соціальний капітал і його суспільна вага визначається відносинами у конкретному суспільстві, які базуються на очікуванні взаємного обміну, а політики й державні діячі набувають своєї політичної сили через довіру, яку довірителі у них вкладають; як «кредит» інтерпретує довіру Т. Парсонс, наголошуючи на тому, що довіра виборців $є$ кредитуванням політики. Цілком обгрунтованим, на нашу думку, є звернення П. Штомпки до ціннісних основ феномену довіри. Науковець справедливо вказує на те, що довіра може виникнути лише на основі спільних цінностей, узгодженості у сприйнятті світу та соціальних практик.

Виклад основного матеріалу. Здавалося б, поняття довіри не потребує особливого пояснення. Це поняття присутнє у нашому лексиконі як очевидна й зрозуміла річ - ним визначаються взаємостосунки, оцінюється ставлення до подій, явищ, процесів тощо. Водночас довіра стала інструментом політичних технологій та знаряддям сугестивного впливу та маніпуляції свідомістю. Не зважаючи на те, що довіра як певний соціально-психологічний, ментальний стан не може бути безпосередньо «виміряною», показник ії (довіри) рівня усе частіше виступає елементом емпіричних досліджень i, попри суб'єктивний характер, набуває ознак об'єктивного й важливого чинника суспільно-політичних процесів. Довірою вимірюється рейтинг політиків, державних діячів та ухвалених ними рішень тощо. Разом з тим, варто враховувати, що довіра - це передусім психологічний феномен, в основі якого - складний процес освоєння світу, самовизначення в ньому, результат соціально-психологічного впливу на особистість, на соціальні групи та суспільство, на цінності і їх систему, на мотиви діяльності та поведінку. Зумовлено це передусім ціннісною природою феномену довіри, соціокультурною детермінацією й амбівалентністю проявів (довіри/недовіри). Та й сама довіра $є$ цінністю, мало того - базовою цінністю, і водночас - підставою оцінки й суджень. Саме тому важливим є розуміння природи феномену довіри, усвідомлення впливу цього явища на соціальні та політичні процеси, їх перебіг і результати.

Політика як теорія і практика, процес і результат організації суспільного життя, сфера взаємовідносин влади та суспільства, функціонування політичних інститутів, поведінки політичних суб'єктів і системи відповідних цінностей і норм, зрештою - як способу мислення і діяльності людей, - завжди є сукупністю дій і взаємодій широкого кола суб'єктів. Окрім інституційних (соціальних, зовнішньо- і внутрішньополітичних тощо), це й групові (формальні й неформальні спільноти), й індивідуальні (на рівні особистостей, як відносно самостійних суб'єктів суспільного життя). У політичному житті, як і в усьому, $є$ і впорядкованість, i хаотичність. С сфери, які пізнаються й оцінюються раціонально, $є$ й такі, які освоюються інтуїтивно, а підставою їх оцінок стають позараціональні складові. Завдяки поєднанню цих елементів нівелюється хаотичність, вибудовується своєрідна «ідеальна» (несуперечлива й цілісна) модель світосприйняття, картини світу.

Цілераціональність (за М. Вебером) державного розвитку, як осмисленого, спрямованого на досягнення цілей поступу із застосуванням визнаних адекватними засобів, $\epsilon$, безумовно, доцільною й обгрунтованою. Саме тому основна увага і в теоретичній, і в практичній площинах державотворення приділяється проблемам становлення й еволюції інститутів (державних, політичних, соціальних тощо), а оцінка сучасних суспільно-політичних процесів (та пошук шляхів їх удосконалення) здебільшого грунтується на аналізі інституційних складових - діяльності державних 
органів, органів місцевого самоврядування, політичних партій, суспільно-політичних рухів, громадських організацій тощо. Вважається, що саме ці- інституційно-організовані суб'єкти як елементи політичної системи зумовлюють її цілісність та визначають рівень ефективності. Насправді ж, функціонування будь-яких суспільних інститутів залежить передусім від міжособистісної та міжгрупової взаємодії, від іiі спрямованості та ефективності. Зрештою, політика робиться людьми й для людей. Саме вони забезпечують діяльність тих чи інших інститутів, продукують процеси і явища, цінності й норми, символи й значення, цінності й ідеали. Спроби ж ототожнення суспільнополітичного розвитку з інституційним, прагнення до абсолютизації інституційної складової колективної та індивідуальної поведінки виявляються малопродуктивними, оскільки такий підхід нівелює значення неполітичних та позараціональних детермінант.

За браком раціональних критеріїв оцінки, на тлі посилення популізму в політиці, зростає вага ірраціональних, емоційних складників оцінних суджень, які грунтуються на інтуїції й вірі. Політична теорія і практика мають враховувати всі сторони життєдіяльності, всі аспекти буття, зокрема, й феномену довіри як об'єктивно непевного, але несуперечливого відчуття істинності. Політична практика свідчить, що довіра, попри те, що вона не завжди грунтується на раціональних засадах, дедалі більше стає невіддільною частиною внутрішньо- i зовнішньополітичних процесів, домінантною основою електорального вибору, складовою оцінки ефективності державного управління, прийняття соціально-політичних рішень, зрештою - легітимації влади.

Унікальність феномену довіри полягає передусім у своєрідному поєднанні раціональних та позараціональних підстав оцінок і суджень. 3 одного боку, вона $\epsilon$ (може бути) результатом апостеріорного пізнання й випливати з досвіду, грунтуватися на аналізі й синтезі подій, явищ, процесів, оцінці поведінки тощо. 3 другого - базуватися не на раціональних засадах, а ірраціональних мотивах з опертям на інтуїцію, власні або ж стереотипні уявлення про належне, бажане, грунтуватися на передбаченні (можливості) розвитку подій, процесів, на вірогідності поведінки об'єкта довіри через переважно емоційне сприйняття.

Людська життєдіяльність неможлива без довіри. Вона формується в перший рік життя дитини через зв’язок з матір'ю («базальна» довіра, за Е. Еріксоном), поступово переноситься на оточення, а 3 часом - стає необхідним компонентом особистісного розвитку [18, с. 108-110]. Від народження безумовна (за А. Селінгменом [9] - «базова») довіра - фундаментальне відчуття, без якого неможливе співіснування з іншими. Від початку довіра грунтується на емпатії- співпереживанні, розумінні відносин, почуттів, психічних станів іншої людини, здатності перейматися ії емоційним станом тощо. Ці, емпатійні, практики супроводжують людину усе іiі життя. Спочатку - на емоційному рівні механізмів проєкції та наслідування, з часом - на когнітивному рівні - порівняння й аналогії, а потім - на новому рівні - здатності передбачати реакції іншої людини в конкретних ситуаціях, прогнозувати їі дії або бездіяльність, розвиток подій.

Важливим, у контексті нашого дослідження, є розуміння довіри як особливої форми поєднання емпатії (емоційної основи цього явища) з процесом ідентифікації (як основи раціональної інтерпретації, ототожнення, співвіднесення себе з певним зразком або моделлю). Результатом такого поєднання $є$ утворення ідентичності - набутого людиною в ході індивідуального розвитку і процесу соціалізації, ідентифікації й особистісної інтеграції стану - динамічної, рухливої, але відносно стійкої рівноваги ціннісних орієнтацій, соціальних ролей і зв'язків, установок, переваг [19]. Саме ці складові, як результат особистісного розвитку, стають основою соціальної, політичної, культурної, етнічної, групової ідентичності тощо. Тож, коли йдеться про ідентичність, мовиться про довіру.

Довіра $є$ ціннісною основою соціальної взаємодії, а ефективність цієї взаємодії базується на збігові цінностей, що й забезпечує ціннісно-орієнтаційну єдність. Саме тому метою кожного політичного режиму є прагнення сформувати систему цінностей, на яку орієнтуватиметься широкий загал. На цьому аспекті цінностей, аналізуючи легітимність як довіру до політичних суб'єктів, наголошував Д. Істон. Дослідник зазначав, що для завоювання ресурсу системної довіри та легітимності влади їй, окрім ціннісних і морально-етичних характеристик (чесність, відповідальність тощо), у своїх діях необхідно орієнтуватися на закладені в цінностях ідеї та норми й забезпечити: регулярність (упорядкованість, підпорядкування законам і нормам); обгрунтованість (пояснення, аргументація власних дій); ефективність (компетентність, дисципліна) [20].

Особливої ваги демократичні принципи забезпечення легітимності влади набувають в контексті вітчизняних реалій - становлення правової держави, іiі політичних інститутів, розвитку громадянського суспільства. В цьому сенсі політична довіра стає надзвичайно важливим чинником державотворчих процесів в умовах національного, державного самовизначення та необхідності 
подолання численних суспільно-політичних криз. Проблема легітимності безпосередньо пов'язує владні інститути з інститутом суспільної довіри в контексті їі (влади) визнання й підтримки. В цьому ж контексті важливим аспектом взаємодії $є$ також довіра між гілками влади, між політичними інститутами, між органами влади різного рівня. Означену проблему на тлі необхідності забезпечення унітарності як форми державного устрою актуалізують і процеси децентралізації як перерозподілу управлінських функцій і передачі їх частини органам місцевого самоврядування. Ці та інші аспекти можуть стати предметом окремих досліджень.

Важливим для розуміння й аналізу феномену довіри $є$ співвіднесення й розмежування понять «довіра» й «віра». Досить часто вони використовуються (зокрема й науковцями) як синоніми. Разом 3 тим, навіть за умови семантичної спорідненості, ці поняття концептуально відрізняються, хоча й залишаються близькими й взаємозумовленими. I якщо віра є категорією безумовною, абсолютною, універсальною й незаперечною, то довіра - це передовсім категорія не лише аксіологічна, але й етична (суспільно-нормативна) та соціальна. В цьому контексті довіра набуває відносно самостійного статусу впливового чинника суспільно-політичних взаємодій.

Звернімо також увагу на поняття «недовіра». Зазвичай, «недовіра» трактується виключно як антонім поняття «довіра». Водночас варто звернути увагу не лише на семантичне розрізнення цих понять, але й соціально-психологічну основу цього розрізнення. Адже очевидно, що недовіра, окрім негативно маркованої емоції, містить елементи критичної оцінки явища, процесу, твердження або ж негативного досвіду, результатів аналізу відповідності риторики поведінці, вчинків тощо. Тобто, сутність розрізнення цих понять полягає передусім у тому, що довіра є здебільшого некритичним сприйняттям дійсності, недовіра ж (сумнів, втрата віри, почуття непевності, підозри, розчарування тощо) - результат досвіду, певного раціонального аналізу, критичної оцінки, відчуження довіри.

Як уже зазначалося, «виміряти довіру», з огляду на переважно суб'єктивний характер цього феномену, досить складно. Чи не єдиним виявом довіри, доступним для спостереження і відносно об’єктивної оцінки (з усіма обмовками, що супроводжують цей суб'єктивний процес), є поведінка, зокрема - політична поведінка. Методологічно важливим $\epsilon$ усвідомлення сув'язності поведінки як зовнішньо спостережуваного акту з його мотиваційно-смисловими основами. Тобто, з одного боку поведінка, на відміну від психіки, є доступною для безпосереднього спостереження й оцінки іiі актуальних проявів. 3 другого - поведінка $€$ процесом і результатом динаміки психофізіологічних та соціально-психологічних характеристик, складної сукупності смислів, мотивів, установок, ціннісних орієнтацій, переконань, усього складного комплексу, який визначає рівень довіри та спонукає до певних, зокрема - політичних, проявів (дії або ж - бездіяльності).

У сучасних соціальних та поведінкових науках поняттям «політична поведінка» позначається сукупність «різноманітних реакцій людини на політичну дійсність і містить у собі як внутрішні рефлексії (думки, сприйняття, установки, переконання тощо), так і практичні дії щодо неї» [21, с. 561]. Складність дослідження ролі й місця довіри та ії впливу на політичну поведінку зумовлена необхідністю аналізу поведінки як цілісності- упоєднанні іiі спонукальних і результативних аспектів. У цій цілісності тісно взаємопов'язаними й взаємозумовленими є загальне й окреме, закономірне й випадкове, формально-нормативне й індивідуально-ціннісне, прагматичне й ірраціональне, доцільне й емоційне тощо. Тобто, як і будь-яка соціальна дія, політична поведінка полягає у виявах політичної активності або ж- у ії відсутності. Серед основних форм політичної активності - участь у діяльності політичних партій, громадських організацій і об'єднань, долученість до суспільно-політичних акцій, до діяльності виборних органів самоуправління, участь в електоральних процесах тощо. Довіра або ж недовіра $є$ одним із чинників, передумов певних виявів політичної поведінки та їх форм [22].

Висновки. Здійснений аналіз дає можливість виокремити певні характеристики й визначити окремі функції довіри як соціокультурного і політико-психологічного феномену. 1) Довіра $€$ надзвичайно складним, багатоаспектним i водночас цілісним, внутрішньо несуперечливим i динамічним соціально-психологічним явищем, який базується на визнанні моральної цінності та упевненості в соціальній надійності «іншого» (людини, групи тощо). 2) Довіра $є$ досить архаїчним і стійким соціокультурним явищем, формою духовного й практичного досвіду і водночасінтуїтивним сприйняттям буття, емоційно-ціннісною основою міжособистісної й міжгрупової взаємодії, співіснування з іншими людьми й зі світом. 3) Довіра - стан очікування в умовах усвідомлення ризику, який характеризується відкритістю, вибірковістю, виступає своєрідною точкою перетину індивідуального й соціального, раціонального та ірраціонального, досвіду взаємодій минулого, оцінки сучасного й проєктування майбутнього. 
За суб'єкт-об'єктними критеріями можна виокремити такі види довіри: міжособистісна; міжгрупова; абстрактна; окремішня; узагальнена; верифікована/неверифікована; предметна; соціальна; політична тощо.

Попередній аналіз дозволяє виокремити також основні соціально-психологічні функції довіри, які впливають на політичну поведінку i, зокрема, на електоральний вибір громадян. 1) Довіра $€$ необхідним елементом соціалізації, ідентифікації й утворення ідентичності, ціннісно-нормативною основою соціальної взаємодії, забезпечення спільної діяльності, перцепції (як забезпечення зв'язку внутрішнього й зовнішнього світу через почуття), групової ідентифікації й диференціації. 2) Важливою функцію довіри є забезпечення легітимності влади. В соціально-політичному контексті довіра виконує функцію суспільної інтеграції й консолідації. Крім того, довіра $є$ своєрідним стрижнем незалежного громадського контролю за діяльністю політичних лідерів і владних інститутів. Серед важливих функцій довіри - налагодження механізмів взаємостосунків через очікування певного способу поведінки інших. У цьому сенсі соціальні очікування набувають характеру мотивів поведінки, поведінкового орієнтира (на підставі узалежнення передбачуваної, очікуваної або ж нормативно закріпленої поведінки). 3) Довіра виконує регуляторну функцію у соціальній взаємодії та значною мірою визначає ефективність цього процесу. 4) Когнітивна функція довіри (прийняття рішення в умовах невизначеності, розв'язання проблемної ситуації). В цьому сенсі особливої ваги набуває становлення й розвиток політичного мислення як процесу оцінки ступеня ризику в умовах невизначеності, непевності, двозначності. Мислення є аналітичною передумовою довіри, результатом визнання або прийняття ситуації ризику в умовах неможливості контролю за перебігом подій. Найважливішою особливістю мислення як діяльності є його суспільна зумовленість - формування за певних соціальних умов. Адже соціальна зумовленість мислення полягає не лише в засвоєнні певних правил, норм і навичок, але й у рефлексії до певних суспільно-історичних умов, через здійснення мислиннєвої діяльності, гармонію співвідношення свідомого і несвідомого в ній. 5) Комунікативна функція в умовах емоційно-чуттєвого контексту ситуації формування довіри під впливом особистої симпатії/антипатії, проявів емпатії тощо. Важливим аспектом цього процесу $є$ інтерактивність комунікації як забезпечення зворотного, діалогового зв'язку поряд з навіюванням (можливістю маніпулятивних впливів з метою формування певної суспільної думки). Довіра є ледь не основним об'єктом маніпуляції свідомістю в процесах електорального вибору. 6) Функція довіри щодо визначення поведінкової стратегії через прогноз поведінки інших та через редукцію - зведення складних систем відносин до порівняно «спрощеного» стану довіри / недовіри, зниження когнітивної складності у стані невизначеності, спрощення прийняття рішень й вибору певної моделі поведінки. В цьому контексті варто виокремити й прогностичну функцію довіри. 7) Довіра виконує й низку функцій, пов'язаних з управлінською діяльністю (використання довіри як управлінського ресурсу), суспільної стабілізації (через формування, підтримання, відтворення й оптимізацію соціальної взаємодії й соціальної структури) та забезпечення самоорганізації суспільства (через актуалізацію моральних основ та соціальних норм співіснування, співробітництва, взаємодопомоги тощо).

Попри все, довіра, зокрема в політичному виборі, залишається здебільшого емоційно-ціннісним, морально-етичним критерієм прийняття рішень. Саме тому варто виходити з необхідності їх обгрунтованості шляхом раціоналізації, підвищення рівня політичної культури, розвитку політичної освіти та критичного мислення.

В умовах колосальної неоднорідності суспільства і його крайньої диференціації не тільки за економічним статусом, але й за світоглядними, політичними, ціннісними установками надзвичайно важливими стають проблеми суспільної консолідації, толерантності, досягнення консенсусу та довіри між окремими соціальними, національними й релігійними групами, довіри суспільства до владних, економічних і правових інститутів.

\section{Бібліографічний список:}

1. Бек У. Общество риска. На пути к другому модерну / пер. с нем. В. Седельника и Н. Федоровой; послесл. А. Филиппова. М. : Прогресс-Традиция, 2000. 384 с.

2. Бурдье П. Социология политики / сост., общ. ред. и предисл. Н. А. Шматко. М. : Socio-Logos, 1993. 336 c.

3. Бурдье П. Формы капитала. DOI: 10.17323/1726-3247-2002-5-60-74

4. Гидденс Э. Устроение общества. Очерк теории структурации / пер. $з$ англ.; 2-е изд. М. : Академический Проект, 2005. 528 c.

5. Lipset S. M. Political Man. Anchor Books, Garden City, New York, 1960. 477p.

6. Луман Н. Власть / пер. с нем. А. Ю. Антоновского. М. : Праксис, 2001. 256 с.

7. Маслоу А. Мотивация и личность / пер. с англ. А. М. Татлыбаевой. Санкт-Петербург : Евразия, 2001. 479 c. 
8. Парсонс Т. Система современных обществ / пер. с англ. Л. А. Седова и А. Д. Ковалева; под ред.

М. С. Ковалевой. М. : Аспект-Пресс, 1998. 270 с.

9. Селигмен А. Проблема доверия / пер. с англ. И. И. Мюрберг, Л. В. Соболевой. М. : Идея-Пресс, 2002. $256 \mathrm{c}$.

10. Фукуяма Ф. Доверие: социальные добродетели и путь к процветанию / пер. с англ. М. : ООО «Издательство АСТ», 2004. 730 с.

11. Sztompka P. Trust: a sociological theory. Cambridge : Cambridge university press, 1999. 214 p.

12. Штомпка П. Доверие в эпоху глобализации. Социальная политика и социиология. 2006. № 4. С. 8-15.

13. Бова А. Довіра до соціальних інститутів: крос-національні зіставлення. Соціальна психологія. 2004.

№ 2 (4). С. 90-99.

14. Общество без доверия / под. ред. Е. Головахи, Н. Костенко, С. Макеева. Киев : Институт социологии НАН Украины, 2014. 338 с.

15. Денисюк С. Г. Довіра як чинник ефективності політичної комунікації. Вісник Харківського національного університету імені В. Н. Каразіна. Серія: Питання політології. 2011. № 984. Вип. 19. С. 171-176.

16. Ручка А. О. Соціокультурне підгрунтя демократичної консолідації. Українське суспільство 1992-2006. Соціологічний моніторинг / за ред. В. Ворони, М. Шульги. Київ : Інститут соціології НАН України, 2006. С. 347-355.

17. Щедрова Г. Чинник довіри як інструмент політичних технологій. Гілея: науковий вісник. 2020. Вип. № 154 (3). С. 335-341.

18. Эриксон Э. Идентичность: юность и кризис / пер. с англ., общ. ред. и предисл. А. В. Толстых.

М. : Издательская группа «Прогресс», 1996. 344 с.

19. Шайгородський Ю. Ціннісні орієнтації в психологічній структурі особистості. Соціальна психологія. 2009. № 4 (36). С. 65-73.

20. Сичова А. Феномен політичної довіри крізь призму концепції легітимності. Науковий вісник Ужгородського університету. Серія: Політологія, Соціологія, Філософія. 2010. Вип. 14. С. 53-55.

21. Постригань Г. Поведінка політична. Політична енциклопедія / редкол.: Ю. Левенець (голова), Ю. Шаповал (заст. голови) та ін. Київ : Парламентське видавництво, 2011. 808 с.

22. Шайгородський Ю. Криза суспільної довіри: суперечність між очікуваннями та реальністю. Політичне поле Украӥни у ситуачії суспільної кризи: влада, опозичія, політичні партії, громадські організації / за ред. О. Майбороди. Київ : ІПіЕнД ім. І. Ф. Кураса НАН України. 264 с.

\section{References:}

1. Bek U. Obshchestvo riska. Na puti k drugomu modernu / per. s nem. V. Sedel'nika i N. Fedorovoy; poslesl. A. Filippova. M. : Progress-Traditsiya, 2000. 384 s.

2. Burd'e P. Sotsiologiya politiki / sost., obshch. red. i predisl. N. A. Shmatko. M. : Socio-Logos, 1993. 336 s.

3. Burd'e P. Formy kapitala. DOI: 10.17323/1726-3247-2002-5-60-74

4. Giddens E. Ustroenie obshchestva. Ocherk teorii strukturatsii / per. z angl.; 2-e izd. M. : Akademicheskiy Proekt, 2005. 528 s.

5. Lipset S. M. Political Man. Anchor Books, Garden City, New York, 1960. 477p.

6. Luman N. Vlast' / per. s nem. A. Yu. Antonovskogo. Moskva : Praksis, 2001. 256 s.

7. Maslou A. Motivatsiya i lichnost' / per. s angl. A. M. Tatlybaevoy. Sankt-Peterburg : Evraziya, 2001. 479 s.

8. Parsons T. Sistema sovremennykh obshchestv / per. s angl. L. A. Sedova i A. D. Kovaleva; pod red.

M. S. Kovalevoy. M. : Aspekt-Press, 1998. 270 s.

9. Seligmen A. Problema doveriya / per. s angl. I. I. Myurberg, L. V. Sobolevoy. M. : Ideya-Press, 2002. 256 s.

10. Fukuyama F. Doverie: sotsial'nye dobrodeteli i put' k protsvetaniyu / per. s angl. Moskva : OOO «Izdatel'stvo AST», 2004. $730 \mathrm{~s}$.

11. Sztompka P. Trust: a sociological theory. Cambridge : Cambridge university press, 1999. 214 p.

12. Shtompka P. Doverie v epokhu globalizatsii. Sotsial'naya politika i sotsiologiya. 2006. № 4. S. 8-15.

13. Bova A. Dovira do sotsialnykh instytutiv: kros-natsionalni zistavlennia. Sotsialna psykholohiia. 2004. № 2 (4). S. 90-99.

14. Obshchestvo bez doveriya / pod. red. E. Golovakhi, N. Kostenko, S. Makeeva. Kiev : Institut sotsiologii NAN Ukrainy, 2014. 338 s.

15. Denysiuk S. H. Dovira yak chynnyk efektyvnosti politychnoi komunikatsii. Visnyk Kharkivskoho natsionalnoho universytetu imeni V. N. Karazina. Seriia: Pytannia politolohii. 2011. № 984. Vyp. 19. S. 171-176.

16. Ruchka A. O. Sotsiokulturne pidgruntia demokratychnoi konsolidatsii. Ukrainske suspilstvo 1992-2006. Sotsiolohichnyi monitorynh / za red. V. Vorony, M. Shulhy. Kyiv : Instytut sotsiolohii NAN Ukrainy, 2006.

S. 347-355.

17. Shchedrova H. Chynnyk doviry yak instrument politychnykh tekhnolohii. Hileia: naukovyi visnyk. 2020. Vyp. № 154 (3). S. 335-341.

18. Erikson E. Identichnost': yunost' i krizis / per. s angl., obshch. red. i predisl. A. V. Tolstykh.

M. : Izdatel'skaya gruppa «Progress», 1996. 344 s. 
19. Shaihorodskyi Yu. Tsinnisni oriientatsii v psykholohichnii strukturi osobystosti. Sotsialna psykholohiia. 2009. № 4 (36). S. 65-73.

20. Sychova A. Fenomen politychnoi doviry kriz pryzmu kontseptsii lehitymnosti. Naukovyi visnyk Uzhhorodskoho universytetu. Seriia: Politolohiia, Sotsiolohiia, Filosofiia. 2010. Vyp. 14. S. 53-55.

21. Postryhan H. Povedinka politychna. Politychna entsyklopediia / redkol.: Yu. Levenets (holova), Yu. Shapoval (zast. holovy) ta in. Kyiv : Parlamentske vydavnytstvo, 2011. $808 \mathrm{s.}$

22. Shaihorodskyi Yu. Kryza suspilnoi doviry: superechnist mizh ochikuvanniamy ta realnistiu. Politychne pole Ukrainy u sytuatsii suspilnoi kryzy: vlada, opozytsiia, politychni partii, hromadski orhanizatsii / za red. O. Maiborody. Kyiv : IPiEnD im. I. F. Kurasa NAN Ukrainy. 264 s.

\section{Shaihorodskiy $Y u$. Trust as a political and psychological phenomenon}

The article is devoted to the analysis of trust as a political and psychological phenomenon. The focus is on the fact that trust is the value basis of social interaction, it is emphasized that the effectiveness of this interaction is based on the coincidence of values, which, to a large extent, ensures value-oriented unity. It is emphasized that the uniqueness of the phenomenon of trust lies in a peculiar combination of rational and irrational bases of assessments and judgments. It is proved that trust, on the one hand, is the result of a posteriori cognition and follows from experience, is based on analysis and synthesis of events, phenomenas, processes, evaluation of behavior, etc., on the other - is based on irrational motives that rely on intuition, own or stereotyped ideas about the proper, desirable, probable because of its predominantly emotional perception. The role of trust as an important factor of state-building processes in the conditions of national, state self-determination and overcoming of social and political crises is substantiated. Particular attention is paid to the role of trust in the process of legitimation of power, the problem of trust in the context of interaction between branches of government, political and state institutions is actualized. It is proved that trust as a political and psychological phenomenon is a powerful factor and regulator of socio-political processes, an element of the architecture of the system of social and institutional interaction and a kind of its provision. In the context of socio-political interaction, the socio-psychological basis for distinguishing between the concepts of "trust" and "faith", "trust" and "distrust" is revealed. The characteristic features and certain functions of trust as a socio-cultural and political-psychological phenomenon are outlined. Emphasis is placed on the cognitive function of trust, in particular, on the need to develop political thinking as an analytical prerequisite for trust and a necessary component of political culture.

Keywords: trust, values, social interaction, political thinking, rational and irrational in politics, political culture. 